\title{
Studies on the protein requirements of growing cattle
}

\author{
Effects of differing intakes of protein and energy on growth and nitrogen \\ metabolism in young entire males
}

\author{
BY T. W. GRIFFITHS \\ The Agricultural Institute, Dunsinea, Castleknock, Co. Dublin, Irish Republic
}

(Received 11 January 1983 - Accepted 9 August 1983)

\begin{abstract}
1. Forty-eight Friesian entire male cattle, with an initial live weight (LW) of $135 \mathrm{~kg}$, were used in two experiments to measure the response to increasing levels of dietary protein (9-11 and 7.5-10.5 g nitrogen $\times 6.25 / \mathrm{kg}$ $\mathrm{LW}^{0 \cdot 75}$ ) at differing energy levels (800-900 $\mathrm{kJ}$ metabolizable energy (ME) $\mathrm{kg} \mathrm{LW} \mathrm{W}^{0 \cdot 75}$ ) over 120-d periods. Digestibility and $\mathbf{N}$ balance measurements were also made during the experiments. The diets, which were based on barley and soya-bean meal, were individually fed twice daily.

2. In a third experiment, similar diets were given to four similar animals fitted with intestinal cannulas, at constant energy intake but with variations in dietary protein of $7.5-13.5 \mathrm{~g} \mathrm{~N} \times 6.25 / \mathrm{kg} \mathrm{LW}^{0.75}$. Chromic oxide paper was used as a digesta marker.

3. Positive responses in $\mathrm{LW}$ gain and $\mathrm{N}$ balance to additional protein were found in both experiments but these were significant $(P<0.05)$ only in the second experiment and were associated with significant $(P<0.01)$ increases in the digestibility of modified acid-detergent fibre and ME intake.

4. Mean values, which were not significantly different between treatments, for the degradability of dietary protein in the rumen and the efficiency of microbial protein synthesis were 0.57 and $31.3 \mathrm{~g} / \mathrm{kg}$ organic matter apparently digested in the rumen respectively. Corresponding values obtained by regression analysis were 0.56 and $28 \cdot 2$.

5. The results in general support the Agricultural Research Council (1980) proposals and suggest that undegraded dietary protein was not limiting in these experiments but that rumen-degradable protein levels were limiting on some treatments.

6. Regression analysis indicated that the mean response to additional protein ( $\mathrm{g} \mathrm{LW}$ gain $/ \mathrm{g} \mathrm{N} \times 6.25$ ) per $\mathrm{kg}$ LW was 0.52 in Expt 1 and 0.51 in Expt 2 . These responses could be largely explained by increases in ME intakes.

7. Measurements of duodenal amino acid flow showed marked increases in essential amino acids (EAA) across the rumen. However, EAA flows, were not significantly increased at higher $\mathrm{N}$ intakes suggesting that protein per se was not limiting in these experiments.
\end{abstract}

The protein requirements of growing cattle have recently been reviewed by Geay (1980). Allowances recommended by various authors varied widely when expressed in terms of digestible crude protein (DCP), but there was a tendency for the more recent recommendations to be lower than earlier estimates. Some of this variation might be due to known limitations of DCP (Miller et al. 1977) and revised recommendations for protein requirements have recently been published (e.g. Agricultural Research Council (ARC), 1980). These recommendations are based on the concepts of rumen-degradable protein (RDP) to satisfy the requirements of the microflora and undegraded dietary protein (UDP) plus microbial protein to meet the requirements of the animal. Whilst these proposals give detailed requirements for various classes of animals and take into account the effect of energy intake on the synthesis of microbial protein, they are based to a considerable extent on information obtained with surgically-modified animals, usually sheep, and consider protein primarily as a source of essential amino acids (AA). In order to apply the ARC (1980) recommendations, it is necessary to have information on the metabolizability of dietary energy and the degradability of dietary protein. Measurements of degradability are technically difficult in vivo, and in vitro results vary with the nature of the diet and need correction for retention time in the rumen (Ganev et al. 1979; Siddons \& Paradine, 1981). A further determinant of animal production is the supply of individual AA to the small 
intestine and it has been pointed out by Miller (1973) that protein requirements must eventually be expressed in terms of essential AA. It is therefore recognized that models such as that proposed by the ARC (1980) require extensive validation and will be subject to periodic revision (Smith, 1982).

The work described in the present paper consists of an evaluation of the responses in young entire male cattle to varying levels of dietary protein in terms of crude protein $(\mathrm{CP}$, nitrogen $\times 6 \cdot 25$ ), DCP, RDP and UDP at different levels of dietary energy intake. Growth, digestibility and $\mathrm{N}$ balance techniques were used and these were supported by measurements of degradability, efficiency of microbial protein synthesis and duodenal AA flow using similar animals fitted with intestinal cannulas. Whilst the results support the concept of RDP and UDP, they illustrate the difficulties of defining dietary requirements for RDP in growing cattle.

\section{EXPERIMEN TAL}

\section{Animals and their management}

Twenty-four Friesian entire male cattle with a mean initial live weight (LW) of $135 \mathrm{~kg}$ were used in each of two growth and balance experiments (i.e. Expts 1 and 2). Animals were assigned to blocks in groups of six according to $\mathrm{LW}$ and within each block were allocated at random to treatments. In each experiment, alternate blocks (i.e. a total of twelve animals) were used for digestibility and balance studies. All animals remained on experiment for $120 \mathrm{~d}$. Food intake was measured daily and LW weekly. Four similar animals fitted with simple cannulas in the rumen and proximal duodenum were used in Expt 3 for measurements of duodenal flow of organic matter $(\mathrm{OM})$ and $\mathrm{N}$. Expt 3 was carried out in two phases using a generalized randomized block design where each phase corresponded to a block. Within each block, each of three treatments were given to two animals in random order. Animals were normally housed in stalls on sawdust bedding with free access to water and given food twice daily. However, selected animals were transferred to metabolism stalls with facilities for the separation and collection of urine and faeces and for the sampling of duodenal contents.

\section{Treatment and diets}

Each animal in all experiments was fed individually and given a basal diet of $0.75 \mathrm{~kg}$ hay and $0.75 \mathrm{~kg}$ ground and pelleted dried grass daily. In Expts 1 and 2 treatments consisted of differing levels of dietary energy ( $\mathrm{kJ}$ metabolizable energy (ME) $\mathrm{kg} \mathrm{LW}^{0.75}$ ) and protein ( $\mathrm{g} \mathrm{N} \times 6.25 / \mathrm{kg} \mathrm{LW}^{0.75}$ ) arranged in $3 \times 2$ factorial layouts as shown in Table 1 . These treatments were designed to supply energy levels sufficient to support rates of LW gain of $0.75-1.0 \mathrm{~kg} / \mathrm{d}$ but with the lowest protein intake being near (Expt 1) or below (Expt 2) ARC (1980) recommendations. The nutritional levels were achieved by alterations (approximately every $28 \mathrm{~d}$ ) in the amounts of supplementary feeds offered. In Expt 1, adjustments were made to the levels of barley and concentrate mixtures A and B, (based on soya-bean meal; for detailed composition, see Table 2). Within any protein level (P2, P3) increases in energy content (E1, E2, E3) were made by increasing the amount of barley and decreasing the amount of concentrate fed. Concentrate A was used for the P2 diets and concentrate B for the P3 diets. In Expt 2, increases in energy intake were made by increasing the amount of barley and protein levels were achieved by the simple substitution of 0.25 and $0.5 \mathrm{~kg}$ soya-bean meal for barley/d. Expt 3 used similar diets to Expt 2 and measured the effects on duodenal flow of nutrients of the substitution of 0.5 and $1.0 \mathrm{~kg}$ soya-bean meal for barley at a constant feed intake of $5 \mathrm{~kg} / \mathrm{d}$. This level was chosen as being appropriate to the use of chromic oxide as a whole digesta marker (Beever et al. 1978). All diets were supplemented with (per kg non-basal diet): retinol equivalent $0.9 \mathrm{mg}$, cholecalciferol $19 \mathrm{mg}$. 
Table 1. Main dietary treatments and approximate dietary levels of energy and protein in each experiment

\begin{tabular}{|c|c|c|c|c|}
\hline \multirow{2}{*}{$\begin{array}{l}\text { Treatment... } \\
\text { Expt }\end{array}$} & \multicolumn{2}{|r|}{ Energy } & \multicolumn{2}{|c|}{ Protein } \\
\hline & Diet & (MJ ME/kg LW L $^{0.75}$ ) & Diet & $\begin{array}{l}\text { (g Nitrogen } \times \\
6 \cdot 25 / \mathrm{kg} \mathrm{LW}^{0} \cdot 75 \text { ) }\end{array}$ \\
\hline 1 & $\begin{array}{l}\mathrm{E} 1 \\
\mathrm{E} 2 \\
\mathrm{E} 3\end{array}$ & $\begin{array}{l}800 \\
850 \\
900\end{array}$ & $\begin{array}{l}\text { P2 } \\
\text { P3 }\end{array}$ & $\begin{array}{r}9 \cdot 0 \\
11 \cdot 0\end{array}$ \\
\hline 2 & $\begin{array}{l}\mathrm{E} 1 \\
\mathrm{E} 2\end{array}$ & $\begin{array}{l}800 \\
850\end{array}$ & $\begin{array}{l}\text { P1 } \\
\text { P2 } \\
\text { P3 }\end{array}$ & $\begin{array}{r}7.5 \\
9.0 \\
10.5\end{array}$ \\
\hline 3 & $\mathrm{E} 2$ & 825 & $\begin{array}{l}\text { P1 } \\
\text { P2 } \\
\text { P3 }\end{array}$ & $\begin{array}{r}7.5 \\
10.5 \\
13.5\end{array}$ \\
\hline
\end{tabular}

ME, metabolizable energy; LW, live weight.

For details of treatments and diets, see p. 134.

Table 2. Mean values for the composition of the feed ingredients used in the experiments $(g / k g D M)$

\begin{tabular}{lllccc}
\hline \hline & & & Nitrogen & \\
Expt & Ingredient & OM & MADF & $6 \cdot 25$ & GE (MJ) \\
\hline 1 & Hay & 941 & 372 & 80 & $18 \cdot 6$ \\
& Dried grass & 931 & 294 & 124 & $18 \cdot 6$ \\
& Barley & 978 & 59 & 99 & $18 \cdot 3$ \\
& Concentrate A* & 922 & 68 & 162 & $17 \cdot 5$ \\
& Concentrate B $\dagger$ & 908 & 80 & 298 & $17 \cdot 9$ \\
& Hay & 925 & 379 & 75 & $18 \cdot 4$ \\
& Dried grass & 914 & 283 & 99 & $18 \cdot 1$ \\
& Barley $\$$ & 970 & 65 & 105 & $18 \cdot 3$ \\
& Soya-bean meal & 934 & 101 & 443 & $19 \cdot 3$ \\
\hline
\end{tabular}

DM, Dry matter; OM, organic matter; MADF, modified acid-detergent fibre; GE, gross energy.

* Composition $(\mathrm{g} / \mathrm{kg})$ : barley 710 , soya-bean meal 200 , molasses 40 , calcium carbonate 30 , sodium chloride 20.

$\dagger$ Composition $(\mathrm{g} / \mathrm{kg})$ : barley 310 , soya-bean meal 600 , molasses $40, \mathrm{CaCO}_{3} 30, \mathrm{NaCl} 20$.

$\ddagger$ Contained $(\mathrm{g} / \mathrm{kg}): \mathrm{CaCO}_{3} 5, \mathrm{NaCl} 5$.

\section{Experimental procedures}

During each $120 \mathrm{~d}$ feeding period in Expts 1 and 2 alternate blocks were transferred to metabolism stalls in groups of six animals for separate collection of urine and faeces over $8 \mathrm{~d}$ periods (Griffiths, 1982) on two occasions after approximately 30 and $90 \mathrm{~d}$ on experiment. In Expt 3 the animals with duodenal cannulas were housed in metabolism stalls for the duration of the experiment. Each of these animals received $2 \times 10 \mathrm{~g} \mathrm{Cr}_{2} \mathrm{O}_{3}$ paper $/ \mathrm{d}$ (Corbett et al. 1960) as an indigestible marker for at least $7 \mathrm{~d}$ before and during the $3 \mathrm{~d}$ sampling period. Diets were given in two equal portions at $12 \mathrm{~h}$ intervals to each animal in random order. Each diet was given for at least $11 \mathrm{~d}$ before sampling began. Samples of duodenal contents were collected manually over $12 \mathrm{~h}$ at intervals of $2 \mathrm{~h}$. These were immediately deep-frozen and subsequently dried at $40^{\circ}$. 


\section{Chemical analyses}

The gross energy (GE), OM, modified acid-detergent fibre (MADF) and $\mathrm{N}$ content of feeds, duodenal digesta (DD) and faeces samples, the $\mathrm{N}$ content of urine samples and the ammonia $\mathrm{N}$ content of DD were determined as previously described (Griffiths \& Smith, 1974). The $\mathrm{Cr}_{2} \mathrm{O}_{3}$ content of the administered paper and DD were determined using an automated colorimetric technique (Christian \& Coop, 1954). AA analysis of feed and DD was carried out by ion-exchange chromatography (Moore et al. 1958) using an automatic AA analyser (Locarte Ltd, London). Samples of feeds and DD were hydrolysed using $6 \mathrm{M}$-hydrochloric acid containing mercapto-ethanol $(1: 2000, \mathrm{v} / \mathrm{v})$ and under an atmosphere of $\mathrm{N}_{2}$ to minimize the losses of methionine (Keutmann \& Potts, 1969). The standard AA programme was modified to obtain separation of 2,6-diaminopimelic acid (DAPA) from methionine and isoleucine.

\section{Calculation of results}

ME intakes were calculated from GE intakes and faecal losses and estimated urinary and methane energy losses (Griffiths, 1978, 1982). The flow of constituents through the duodenum was calculated using $\mathrm{Cr}_{2} \mathrm{O}_{3}$ as an indigestible marker (MacRae \& Armstrong, 1969). Bacterial protein synthesis was calculated from the duodenal passage of DAPA assuming that bacteria contain $44 \mathrm{mg} \mathrm{DAPA} / \mathrm{g} \mathrm{N}$. This value was chosen as being typical for mixed hay concentrate diets (Hutton et al. 1971; Ling \& Buttery, 1978; Chamberlain et al. 1982). The flow of undegraded food protein to the intestine was estimated by difference from duodenal non-ammonia N (NAN) after an arbitrary correction of $2.7 \mathrm{~g} \mathrm{~N} / \mathrm{kg} \mathrm{DM}$ passing the duodenum had been made for protein of endogenous origin (Van't Klooster \& Rogers, 1969).

\section{Statistical assessment}

Values from Expts 1 and 2 were subjected to analysis of variance as a $3 \times 2$ factorial. Effects of blocks, treatments and interactions were removed. Comparisons between treatment means were based on $15 \mathrm{df}$. In the digestibility and balance values each collection period was considered to be independent. In Expt 3, the effects of blocks, treatments and treatments $\times$ blocks were removed in the analysis of variance. The interaction term being non-significant, it was combined with the residual component to form experimental error $(8 \mathrm{df})$. A programme for parallel regression was used to fit models to the values from Expts 1 and 2 for the relationship between LW gain and protein and energy intake. Duodenal flow measurements were analysed using the regression equation of Hvelplund et al. (1976) which is of the form $Y=A+b / X$ where $A$ represents the proportion of dietary $\mathrm{N}$ entering the small intestine undegraded, $b$ the amount of microbial $\mathrm{N}$ synthesized $/ \mathrm{kg} \mathrm{DM}$ ingested, $Y$ the value of the ratio, duodenal NAN: feed $\mathrm{N}$ and $X$ the $\mathrm{N}$ content of the $\operatorname{diet}(\mathrm{g} / \mathrm{kg} \mathrm{DM})$.

RESULTS

\section{Chemical composition of the diets}

The chemical composition and the GE of the feed ingredients used in the experiments are given in Table 2. Dried grass with a low protein content was used in Expts 2 and 3; the soya-bean meal used in these experiments also had lower protein and higher fibre contents than normally found.

\section{Food intake and $L W$ gain}

One animal was withdrawn from Expt 1 after $83 \mathrm{~d}$ due to chronic bloat and one animal died accidentally after $106 \mathrm{~d}$ in Expt 2; otherwise the health of the animals was good throughout. Missing values were calculated for the digestibility data in Expt 2. Mean values 
Studies on the protein requirements of growing cattle

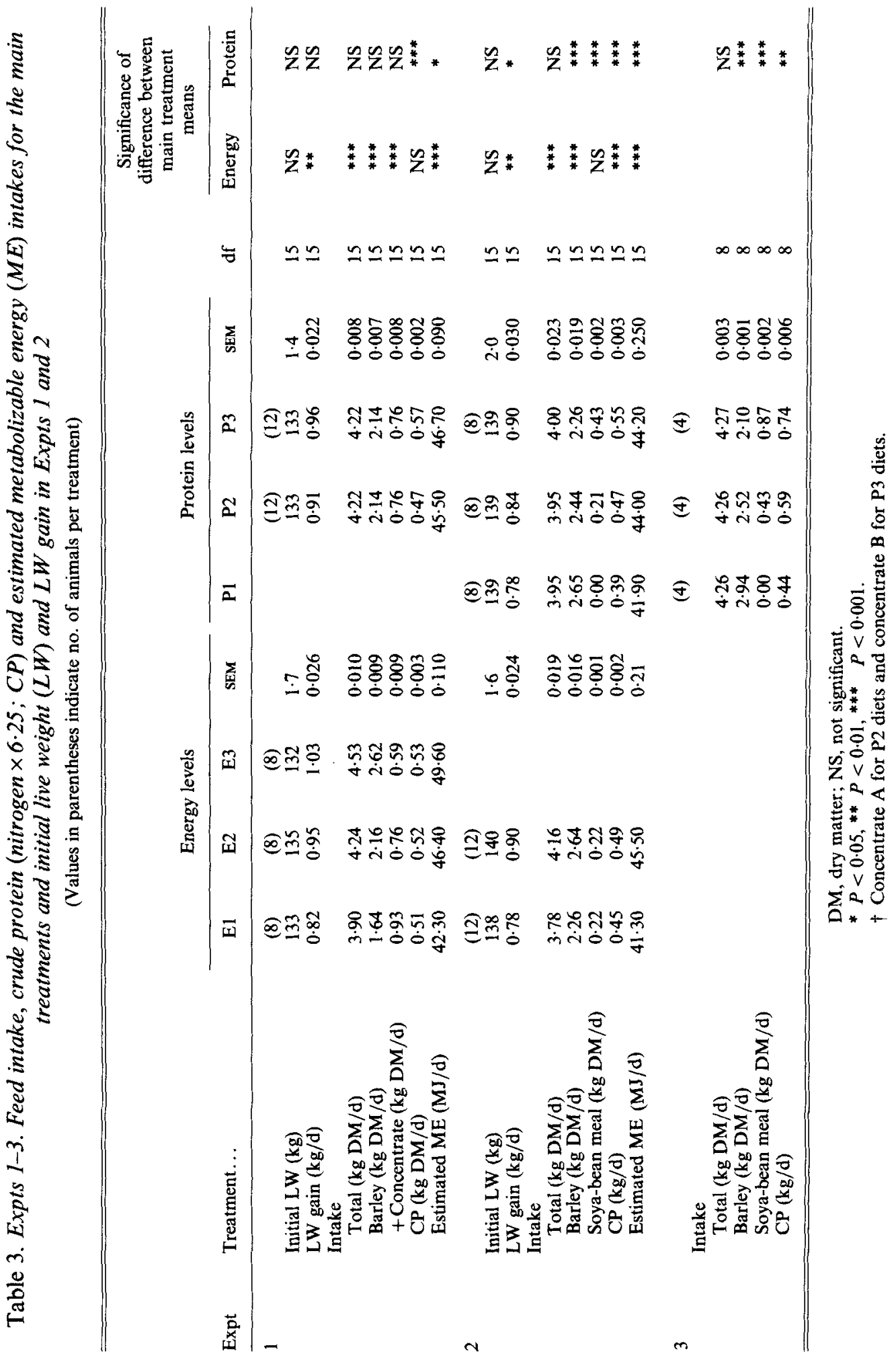







Table 5. Expt 3. Organic matter $(O M)$ and nitrogen intakes, $O M$, total $N$, non-ammonia $N(N A N)$, bacterial $N$ and undegraded food $N$ flowing through the duodenum, the effeciency of microbial protein synthesis and the apparent degradability of dietary protein for diets used

(Mean values for four animals)

\begin{tabular}{|c|c|c|c|c|c|}
\hline Protein level ${ }^{*} \ldots$ & P1 & $\mathrm{P} 2$ & P3 & SEM & $\mathrm{df}$ \\
\hline OM intake $(\mathrm{kg} / \mathrm{d})$ & 4.05 & 4.05 & 4.05 & 0.003 & 8 \\
\hline $\mathrm{N}$ intake $(\mathrm{g} / \mathrm{d})$ & 70 & 95 & 119 & 1.05 & 8 \\
\hline \multicolumn{6}{|l|}{ Flow at the duodenum } \\
\hline $\mathrm{OM}(\mathrm{kg} / \mathrm{d})$ & $2 \cdot 10$ & 1.99 & $2 \cdot 03$ & $0 \cdot 053$ & 8 \\
\hline Total N (g/d) & 106 & 123 & 124 & $1 \cdot 5$ & 8 \\
\hline $\operatorname{NAN}(\mathrm{g} / \mathrm{d})$ & 98 & 115 & 116 & 1.9 & 8 \\
\hline Bacterial N (g/d) & 62 & 65 & 63 & $4 \cdot 0$ & 8 \\
\hline Undegraded food $\mathrm{N} \dagger$ & 29 & 43 & 46 & $2 \cdot 6$ & 8 \\
\hline \multicolumn{6}{|l|}{$\begin{array}{l}\text { Efficiency of microbial protein } \\
\text { synthesis }(\mathrm{g} \mathrm{N} / \mathrm{kg} \mathrm{OM}\end{array}$} \\
\hline $\begin{array}{l}\text { apparently digested in the } \\
\text { rumen) }\end{array}$ & 32 & 32 & 31 & $2 \cdot 8$ & 8 \\
\hline $\begin{array}{l}\text { Apparent degradability of } \\
\text { dietary protein }\end{array}$ & 0.57 & 0.54 & 0.61 & 0.05 & 8 \\
\hline
\end{tabular}

* For details, see Table 1 .

$\dagger$ Undegraded food $\mathrm{N}(\mathrm{g} / \mathrm{d})=$ duodenal NAN $-($ microbial $\mathrm{N}+2 \cdot 7 \times$ duodenal dry matter $(\mathrm{kg}))$.

for daily DM, crude protein (CP) and estimated ME intakes and LW gains for each main treatment in Expts 1 and 2 are given in Table 3 together with feed intake values for Expt 3. (ME intakes were calculated from values obtained in the digestibility trials, see p. 136.) Interactions were not significant and the significance of the main effects are given. In the first experiment, DM intake and LW gains were significantly higher on the higher energy diets $(P<0.01)$. Increased protein intake had no significant effect on LW gains. In the second experiment, LW gains were significantly increased both by the higher energy $(P<0.01)$ and the higher protein diets $(P<0.05)$. In the third experiment, DM intakes were similar but $\mathrm{CP}$ intakes were significantly different $(P<0.001)$.

\section{Digestibility and $N$ balance}

Table 4 summarizes the mean values for the apparent digestibility of OM, MADF, N and $\mathrm{GE}$, the $\mathrm{N}$ balance results and the estimated ME intake for the main dietary treatments used in Expts 1 and 2. Again, interactions were not significant and the significance of the main effects is given. Variations in energy intake had no significant effect on the digestibility of OM, MADF or GE in either experiment. Lower protein intakes depressed the digestibility of MADF in both experiments $(P<0.001$ in Expt 2$)$ with consequent depressions in the digestibility of $\mathrm{OM}$ and GE. Apparent digestibility of $\mathrm{N}$ was also significantly depressed on the lower protein diets in both experiments $(P<0.001)$.

Higher energy intakes were associated with higher faecal $\mathrm{N}$ excretion and higher $\mathrm{N}$ intakes with higher urinary $\mathrm{N}$ excretion. Although $\mathrm{N}$ balance was increased at the higher protein intakes in Expt 1, the effect was not significant. However, $\mathrm{N}$ balance was significantly increased at the highest protein intake in Expt $2(P<0.05)$. Estimated ME intakes $(\mathrm{MJ} / \mathrm{kg}$ DM) were significantly $(P<0.05)$ depressed on the lowest protein diets in Expt 2 due to the effect on digestibility mentioned previously. 
Table 6. Expt 3. The quantities $(\mathrm{g} / \mathrm{d})$ of amino acids consumed and entering the small intestine of cattle for each treatment

(Mean values for four animals)

\begin{tabular}{|c|c|c|c|c|c|c|c|c|c|}
\hline \multirow[b]{2}{*}{ Treatment*... } & \multicolumn{3}{|c|}{ Consumed } & \multirow[b]{2}{*}{ SEM } & \multicolumn{3}{|c|}{$\begin{array}{c}\text { Entering small } \\
\text { intestine }\end{array}$} & \multirow[b]{2}{*}{ SEM } & \multirow[b]{2}{*}{ df } \\
\hline & P1 & $\mathbf{P} 2$ & P3 & & P1 & $\mathbf{P} 2$ & P3 & & \\
\hline Aspartic acid & $26 \cdot 6$ & $44 \cdot 1$ & $61 \cdot 6$ & $0 \cdot 13$ & $50 \cdot 5$ & $58 \cdot 8$ & $56 \cdot 4$ & $2 \cdot 33$ & 8 \\
\hline Threonine & $13 \cdot 1$ & $17 \cdot 3$ & $21 \cdot 5$ & 0.04 & $23 \cdot 4$ & $26 \cdot 4$ & $25 \cdot 2$ & 0.38 & 8 \\
\hline Serine & $17 \cdot 0$ & 23.8 & $30 \cdot 7$ & 0.06 & $25 \cdot 2$ & 28.4 & $27 \cdot 0$ & 0.54 & 8 \\
\hline Glutamic acid & $78 \cdot 4$ & 98.8 & $119 \cdot 2$ & $0 \cdot 20$ & $60 \cdot 3$ & 68.3 & $64 \cdot 1$ & $3 \cdot 22$ & 8 \\
\hline Proline & $33 \cdot 9$ & $36 \cdot 8$ & $39 \cdot 8$ & 0.05 & $17 \cdot 4$ & $21 \cdot 3$ & $20 \cdot 0$ & 0.83 & 8 \\
\hline Glycine & $15 \cdot 5$ & 20.7 & $25 \cdot 9$ & 0.05 & $47 \cdot 9$ & $50 \cdot 0$ & $50 \cdot 2$ & 1.63 & 8 \\
\hline Alanine & $17 \cdot 8$ & $23 \cdot 3$ & $28 \cdot 7$ & 0.05 & $30 \cdot 2$ & 33.7 & 33.6 & 0.59 & 8 \\
\hline Valine & $12 \cdot 9$ & $15 \cdot 2$ & $17 \cdot 5$ & 0.02 & 18.9 & 19.9 & $20 \cdot 4$ & 0.35 & 8 \\
\hline Methionine & $4 \cdot 2$ & $5 \cdot 4$ & $6 \cdot 6$ & 0.01 & $7 \cdot 8$ & 8.7 & 8.8 & 0.42 & 8 \\
\hline Isoleucine & $11 \cdot 5$ & $14 \cdot 1$ & $16 \cdot 6$ & 0.03 & $15 \cdot 4$ & $17 \cdot 4$ & $16 \cdot 7$ & 0.83 & 8 \\
\hline Leucine & 26.0 & 34.8 & $43 \cdot 6$ & 0.08 & $32 \cdot 4$ & $36 \cdot 3$ & $36 \cdot 1$ & 0.91 & 8 \\
\hline Tyrosine & $13 \cdot 7$ & $18 \cdot 1$ & $22 \cdot 5$ & 0.04 & $23 \cdot 3$ & $24 \cdot 5$ & $26 \cdot 4$ & 0.91 & 8 \\
\hline Phenylalanine & $18 \cdot 1$ & 23.7 & $29 \cdot 3$ & 0.05 & $23 \cdot 8$ & $27 \cdot 1$ & $29 \cdot 8$ & 1.69 & 8 \\
\hline Histidine & $7 \cdot 3$ & 10.6 & 13.9 & 0.03 & 9.0 & $10 \cdot 0$ & $10 \cdot 2$ & 0.29 & 8 \\
\hline Lysine & $14 \cdot 0$ & $23 \cdot 1$ & $32 \cdot 3$ & 0.07 & $31 \cdot 3$ & 34.9 & $35 \cdot 8$ & $1 \cdot 64$ & 8 \\
\hline Arginine & $16 \cdot 8$ & $26 \cdot 6$ & $36 \cdot 3$ & 0.08 & $19 \cdot 2$ & $23 \cdot 4$ & $22 \cdot 1$ & 0.41 & 8 \\
\hline Total & 327 & 436 & 546 & 0.8 & 439 & 493 & 486 & $12 \cdot 6$ & 8 \\
\hline
\end{tabular}

* For details, see Table 1.

\section{Duodenal flow of $O M, N$ and $A A$}

Mean values for $\mathrm{OM}$ and $\mathrm{N}$ intake and the duodenal flow of OM, total N, NAN, microbial $\mathrm{N}$ and undegraded feed $\mathrm{N}$ on diets used in Expt 3 are given in Table 5. There were no significant differences between treatments in OM intake or duodenal OM flow. Total $\mathrm{N}$, NAN and undegraded feed $N$ flows were all significantly $(P<0.05)$ higher on the higher protein diets. Differences in the efficiency of microbial protein production per $\mathrm{kg} \mathrm{OM}$ apparently digested in the rumen (OMDR) and apparent degradability of dietary protein were not significant. There was a net gain of $\mathrm{N}$ between the mouth and the duodenum on all diets. The derived regression equation (Hvelplund et al. 1976) for the duodenal $\mathrm{N}$ flow measurements was:

$$
Y=0 \cdot 44(\operatorname{SE} 0 \cdot 15)+14 \cdot 1(\operatorname{SE~} 3 \cdot 05) / X\left(r^{2} 0 \cdot 66\right)
$$

This would suggest that the mean degradability of dietary protein was 0.56 and that the mean efficiency of microbial protein synthesis was equivalent to $28 \mathrm{~g} / \mathrm{kg}$ OMDR since on average $50 \%$ of the OM disappeared between the mouth and the duodenum. Table 6 shows the dietary intake of individual AA and the corresponding flow at the duodenum for the three diets used in Expt 3. Intakes of all AA were significantly different $(P<0.001)$ on each treatment. There was a net gain of most essential AA, in particular threonine, methionine and lysine, between the mouth and the duodenum. Duodenal flows of all AA were similar on the P2 and P3 diets but were lower on the P1 diet. Treatment differences were not significant for threonine, methionine or lysine and were significant only for arginine $(P<0.01)$. 
Table 7. Expts 1 and 2. Mean values for the mean live weight $(\mathrm{LW} ; \mathrm{kg})$ of the animals, the metabolizability (Q) of the diets and the daily intake $(\mathrm{kg})$ of digestible crude protein $(D C P)$, undegraded dietary protein $(U D P)$ and rumen-degradable protein $(R D P)$ for each treatment

\begin{tabular}{|c|c|c|c|c|c|c|c|c|c|c|c|c|}
\hline \multirow{3}{*}{$\begin{array}{l}\text { Energy level... } \\
\text { Protein level... }\end{array}$} & \multicolumn{6}{|c|}{ Expt 1} & \multicolumn{6}{|c|}{ Expt 2} \\
\hline & \multicolumn{2}{|c|}{ El } & \multicolumn{2}{|c|}{ E2 } & \multicolumn{2}{|c|}{ E3 } & \multicolumn{3}{|c|}{ E1 } & \multicolumn{3}{|c|}{ E2 } \\
\hline & $\mathbf{P} 2$ & P3 & $\mathbf{P} 2$ & P3 & $\mathbf{P} 2$ & P3 & P1 & P2 & P3 & P1 & $\mathbf{P} 2$ & P3 \\
\hline LW & 182 & 179 & 188 & 195 & 193 & 195 & 180 & 185 & 191 & 189 & 193 & 197 \\
\hline$Q$ & 0.59 & 0.59 & 0.59 & 0.59 & 0.60 & 0.61 & 0.57 & 0.61 & 0.61 & 0.59 & 0.60 & 0.60 \\
\hline DCP & $0 \cdot 30$ & 0.38 & 0.30 & 0.36 & $0 \cdot 30$ & 0.34 & 0.20 & 0.28 & 0.36 & 0.23 & 0.31 & 0.37 \\
\hline UDP & $0 \cdot 18$ & 0.23 & 0.19 & 0.23 & 0.19 & 0.23 & $0 \cdot 15$ & 0.18 & 0.21 & $0 \cdot 16$ & 0.19 & 0.23 \\
\hline RDP & 0.27 & 0.34 & 0.29 & 0.35 & 0.29 & 0.34 & 0.22 & 0.27 & 0.32 & 0.25 & 0.29 & 0.34 \\
\hline
\end{tabular}

\section{DISCUSSION}

The requirements of ruminants for protein have traditionally been derived by feeding increased dietary levels with the object of determining the point of maximum response (Miller, 1973). The results of the experiments reported in the present paper and other work (e.g. Kay et al. 1968; Griffiths, 1978) illustrate the limitations of this approach since in all cases small positive responses were found in both $\mathrm{LW}$ gain and $\mathrm{N}$ retention to additional protein. These responses were significant only in Expt 2 where associated effects on digestibility were also found.

Measurements of the in vivo degradability of dietary protein, necessary for the validation of the ARC (1980) recommendations, require reliable estimates of duodenal OM flow and microbial protein synthesis. In addition, assumptions regarding endogenous $\mathbf{N}$ secretion are important particularly where low- $\mathrm{N}$ diets are used. The values for endogenous $\mathrm{N}$ used in the present work were similar to those recently suggested by Ørskov \& MacLeod (1983). Values obtained for the efficiency of microbial protein synthesis were near to the value of $30 \mathrm{~g} \mathrm{~N} / \mathrm{kg}$ OMDR used by the ARC (1980). There was a high error associated with the measurement of bacterial $\mathrm{N}$ flow and of degradability of dietary protein in the present work, and treatment differences were not significant. Similar variation has also been found by other workers (Thomson et al. 1981; Chamberlain et al. 1982) for those measurements which are dependent on the use of markers. The estimation of microbial protein synthesis from a single DAPA:N value taken from other work may contribute to this error since there is abundant evidence that DAPA:N values in rumen bacteria vary with the nature of the diet (Ling \& Buttery, 1978). However, the agreement between the value for degradability obtained using this method and the regression technique of Hvelplund et al. (1976) suggest that the error associated with the use of a single DAPA:N value may not have been high in this case. The ARC (1980) allocate feed ingredients to broad groups only for protein degradability. It is suggested that the degradability of protein in these experiments should be taken as $0 \cdot 60$, i.e. a rounded mean value derived from both DAPA and regression analysis.

Mean values for the mean LW of the animals, the metabolizability $(Q)$ of the diets and the daily intake of DCP, UDP and RDP for each treatment in both experiments are presented in Table 7. Compared with ARC (1980) recommendations for bulls of large mature size (LW $200 \mathrm{~kg}, Q 0.6$ ), it would appear that UDP was not limiting in these experiments. It is, however, probable that RDP was limiting on the lower protein diets since there was a significant depression in the digestibility of MADF in both experiments and 


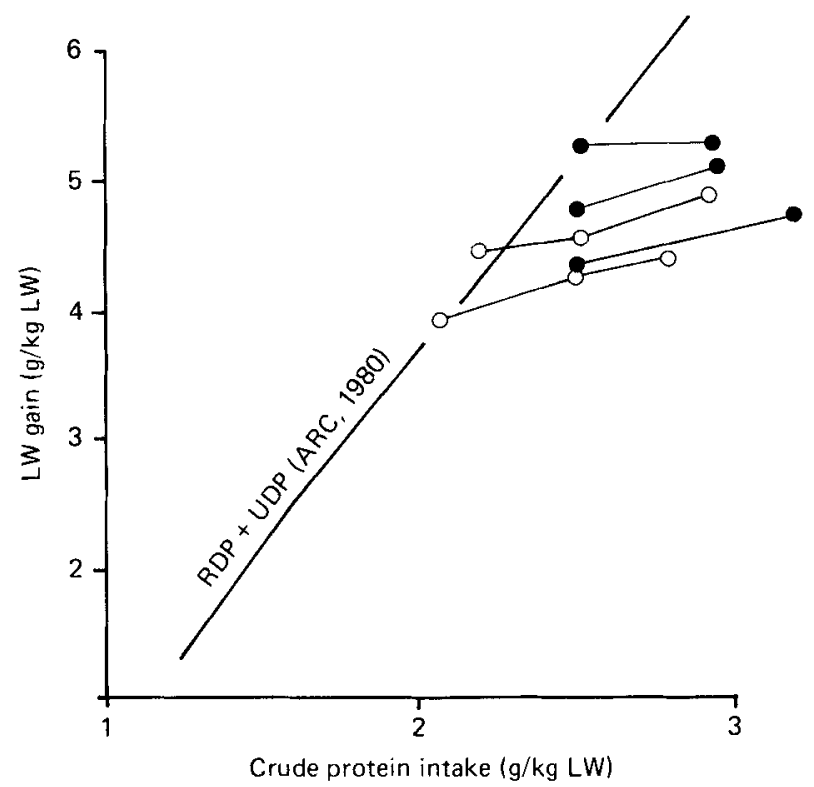

Fig. 1. Relationships between treatment mean values for crude protein (nitrogen $\times 6.25)$ intake and live weight (LW) gain in Expt $1(O)$ and Expt $2(O)$ compared with Agricultural Research Council (ARC, 1980) recommendations for rumen-degradable protein (RDP) and undegraded dietary protein (UDP) for animals of $200 \mathrm{~kg} \mathrm{LW}$.

the RDP levels were in general below the ARC (1980) recommendations. DCP levels agree with the results of Andersen \& Foldager (1980) but were in general lower than most recommended values quoted by Geay (1980). It is of interest to note that there was a close similarity between DCP and RDP values.

The relationship between protein intake (RDP + UDP) and LW gain, both scaled for LW, has been plotted in Fig. 1 along with ARC (1980) recommendations (bulls of large mature size, $200 \mathrm{~kg} \mathrm{LW}, Q 0 \cdot 6$ ). These values broadly fit the model of Balch (1967) for situations where energy is limiting. Regression analyses show that within each experiment the response in LW gain to additional CP was not significantly different at each energy level and the results could be represented by parallel equations. The mean response in $\mathrm{LW}$ gain (g/kg LW) to additional CP (g/kg LW) was 0.52 (SE 0.20) in Expt 1 and 0.51 (sE 0.17) in Expt 2 . These responses, although small in practical terms, can be largely explained by differences in ME intake. Recommended allowances (ARC, 1980) suggest a ME requirement of approximately $18 \mathrm{MJ} / \mathrm{kg} \mathrm{LW}$ gain for animals of this type.

The ideal system for calculating the $\mathrm{N}$ requirements of ruminants must provide estimates of the total and individual AA absorbed from the small intestine, and information on duodenal flow of AA is but a first step. Whilst there is considerable information on duodenal flow of AA in sheep and dairy cows, there are few values for growing cattle of around $200 \mathrm{~kg}$ LW (Thomson et al. 1981). The results presented agree broadly with the values of McMeniman \& Armstrong (1979) for animals of similar LW and range of OM and N intakes. It is possible that methionine might be the first limiting AA on diet P1 in Expt 3 since levels of lysine and threonine were well above those suggested by Fenderson \& Bergen (1975). However, the lack of a significant difference between treatments for the duodenal flow of methionine suggests that AA supply per se was not limiting in these experiments.

The author wishes to thank Messrs T. B. Lynch and F. McGovern for technical assistance, 
Mr T. A. Spillane and his staff for chemical analyses, Dr D. B. R. Poole and Mr P. A. M. Rogers for the cannulation of the animals and Dr D. Harrington for statistical advice.

\section{REFEREN CES}

Agricultural Research Council (1980). The Nutrient Requirement of Ruminant Livestock. Slough: Commonwealth Agricultural Bureaux.

Andersen, R. H. \& Foldager, J. (1980). Annales de Zootechnie hors série 29, 387-391.

Balch, C. C. (1967). World Review of Animal Production 3, 84-91.

Beever, D. E., Kellaway, R. C., Thomson, D. J., MacRae, J. C., Evans, C. C. \& Wallace, A. S. (1978). Journal of Agricultural Science, Cambridge 90, 157-163.

Chamberlain, D. G., Thomas, P. C. \& Wait, M. K. (1982). Grass and Forage Science 37, 159-164.

Christian, K. R. \& Coop, M. R. (1954). New Zealand Journal of Science and Technology A36, 328.

Corbett, J. L., Greenhalgh, J. F. D., McDonald, J. \& Florence, E. (1960). British Journal of Nutrition 14, $289-299$.

Fenderson, C. L. \& Bergen, W. G. (1975). Journal of Animal Science 41, 1759-1766.

Ganev, G., Ørskov, E. R. \& Smart, R. (1979). Journal of Agricultural Science, Cambridge 93, 651-656.

Geay, Y. (1980). In Proceedings of the 3rd EAAP Symposium on Protein Metabolism and Nutrition, publication no. 27, pp. 803-822 [H. J. Oslage and K. Rohr, editors]. Braunschweig, Fed. Rep. Germany: European Association of Animal Production.

Griffiths, T. W. (1978). Animal Production 26, 233-243.

Griffiths, T. W. (1982). Animal Production 34, 309-314.

Griffiths, T. W. \&'Smith, F. H. (1974). Journal of Agricultural Science, Cambridge 83, 531-537.

Hutton, J., Bailey, F. J. \& Annison, E. F. (1971). British Journal of Nutrition 25, $165-173$.

Hvelplund, T., Møller, P. D., Madsen, J. \& Hesscloholt, M. (1976). Kongelige Veterinaer og Landbohoiskoles Aarsskrift 173-192.

Kay, M., Bowers, H. B. \& McKiddie, G. (1968). Animal Production 10, 37-42.

Keutmann, H. T. \& Potts, J. T. (1969). Analytical Biochemistry 29, 175-185.

Ling, J. R. \& Buttery, P. J. (1978). British Journal of Nutrition 39, 165-179.

McMeniman, N. E. \& Armstrong, D. G. (1979). Journal of Agricultural Science, Cambridge 93, 181-188.

MacRae, J. C. \& Armstrong, D. G. (1969). British Journal of Nutrition 23, 15-23.

Miller, E. L. (1973). Proceedings of the Nutrition Society 32, 79-84.

Miller, E. L., Balch, C. C., Ørskov, E. R., Roy, J. H. B. \& Smith, R. H. (1977). Proceedings of the 2nd EAAP Symposium on Protein Metabolism and Nutrition, publication no. 22, pp. 137-141. Wageningen, The Netherlands: European Association of Animal Productions.

Moore, S., Spackman, D. M. \& Stein, W. M. (1958). Analytical Chemistry 30, 1185-1190.

Ørskov, E. R. \& MacLeod, N. (1983). Proceedings of the Nutrition Society 42, 61A.

Siddons, R. C. \& Paradine, J. (1981). Journal of the Science of Food and Agriculture 32, 973-981.

Smith, R. H. (1982). In Forage Protein in Ruminant Animal Production, British Society of Animal Production, Occasional Publication no. 6, pp. 99-106 [D. J. Thomson, D. E. Beever and R. G. Gunn, editors]. Thames Ditton: British Society of Animal Production.

Thomson, D. J., Beever, D. E., Lonsdale, C. R., Haines, M. J., Cammell, S. B. \& Austin, A. R. (1981). British Journal of Nutrition 46, $193-207$.

Van't Klooster, A. T. \& Rogers, P. A. M. (1969). Mededelingen Landbouwhogeschool, Wageningen 11, 3-19. 